\title{
The Influence of Customer Retention Time on Slogan Recall and Recognition: An Empirical Study
}

\author{
Paulo Duarte Silveira ${ }^{1 *}$, Susana Galvão ${ }^{2}$, Paulo Bogas $^{3}$
}

\begin{abstract}
:
This research intends to explore some of the roots that might influence the effectiveness of slogans. The specific aim of the study is to examine the relationship between the customer retention time and the recall and recognition of brand slogans.

This is as an important issue to be studied on branding, because no previous studies were found, and the better understanding of such relationship will help on deciding which marketing mix elements should be managed in order for the brands to obtain a more memorable and stable position in the consumers' mind.
\end{abstract}

An empirical quantitative study was conducted with an online survey research method employed to collect data from 370-real consumers of three B2C brands in telecom industry.

The results revealed that customer seniority (retention time) did not significantly influence slogan recall nor recognition.

Keywords: Slogans; Branding; Positioning; Advertising.

JEL Classification: M31, M37.

\footnotetext{
${ }^{1}$ College of Business Administration-Polytechnic Institute of Setúbal, Setúbal, Portugal, and CEFAGE-UE, Évora, Portugal. Corresponding author email: paulo.silveira@esce.ips.pt

${ }^{2}$ College of Business Administration-Polytechnic Institute of Setúbal, Setúbal, Portugal.

${ }^{3}$ College of Business Administration-Polytechnic Institute of Setúbal, Setúbal, Portugal.

* Authors are grateful to the anonymous participants in the study and their responses to the survey. The authors also acknowledge the support from the affiliation institutions IPS and CEFAGE-UE.
} 


\section{Introduction}

Supphellen and Nygaardsvik (2002) claimed that "Brand slogans are short phrases that communicate descriptive or persuasive information about a brand". Therefore, slogans are an element of the marketing and advertising input, since they convey a marketing message (Vakratsas and Ambler, 1999), with the purpose of establishing an image, identity, or position for a brand to increase its memorability on individuals (O'guinn et al., 2011).

Brand slogans are usually believed to facilitate learning about some aspect of a brand or company (Briggs and Janakiraman, 2017; Dass et al., 2014) by inspiring lasting impressions and favorable memories about specific attributes or values delivered by the respective brand (Strutton and Roswinanto, 2014). More specifically, according to Dowling and Kabanoff (1996) slogans are generally used in marketing due to several possible reasons: ask for customer action, differentiate the company/brand, explain a name, explain a field of operation, identify with a customer group societal concern, make a promise, provide a call to action, provide a reason to buy, remind the corporate vision, rent the image, state a distinctive competence or strategy. Therefore, slogans are an important element in marketing and branding, because of their possible positive influence on increasing awareness and establishing or reinforcing the brand intended identity and positioning (Briggs and Janakiraman, 2017; Hodges et al., 2014; Miller and Toman, 2014; 2015; Dahlén and Rosengren, 2005; Pryor and Brodie, 1998; Boush, 1993; Keisidou et al., 2013).

In order to be able to achieve those benefits on brand equity slogans need to be notice and, for that reason, the effectiveness of a particular slogan is often measured by the ability of the individuals to recall it (Rosengren and Dahlén, 2006; Bauerly and Tripp, 1997; Molian, 1993). However, it is difficult to achieve those benefits, because the correct linkage slogan-brand needs time and significant effort (Huang and Lin, 2017), and also because the slogan may harm the brand, due to the fact that consumers might perceive it as a persuasion tactic (Laran et al., 2011).

Based on the previously mentioned slogan recall importance, Kohli et al. (2013) refer that the two most effective advertising slogans are "Just Do it" (Nike) and "I' $m$ loving it" (McDonald's). Some companies change their slogans every few years e.g. Coke ("Share a Coke" to "Open Happiness" to "The Coke Side of Life"), Burger King ("Have it your way" to "Be your way") and Adidas ("Impossible is Nothing" to "Is all in"). The implication is that such change limits the slogan remembrance, thus demanding a new substantial marketing effort for the new slogan to be learned (Kohli et al., 2013), and, therefore, those brands must invest heavily over a long period in order to (re)generate high levels of recall and reap the potential slogan benefits (Briggs and Janakiraman, 2017).

Previous slogan-related research has been mainly focused on analyzing slogans' ideal characteristics, effects of brand awareness, issues concerning how to make a 
slogan memorable, relationships between consumer demographic characteristics, and slogan learning and assessment (Wang et al., 2016). Previous research has sometimes been based on the researchers and managers own evaluations (Galí et al., 2016) and there is still a lack of literature on the influence of extrinsic factors that might influence the effectiveness of slogans. The present research aims to bridge this gap, by contributing to better understand if customer retention time has influence on the effectiveness of slogans. In other words, the purpose is to analyze if the most senior customers of a particular brand do remember more effectively the slogan of the respective brand than the more recent customers (or non-customers).

In addition to this introduction, the paper has four other sections. The next section is the problem formulation, presenting a literature review and hypotheses formulation. Then, the research methods used are described, followed by the presentation of results. Finally, the paper summarizes the conclusions, identifies limitations and offers avenues for further research.

\section{Problem Statement}

According to Dahlén and Rosengren (2005), consumers use constructive memory to link slogans to brands when a brand name is not provided. Kohli et al. (2013) argue that this is why familiar slogans help individuals to remember where they may have seen/heard it, and which brands they are linked to, thus potentiating brand building by the transference of the brand associations from the slogan to the brand. The same authors mention that this fact highlights the relevance of spontaneous recall of slogans to assess their contribution to the respective brands. To achieve such contribution to brand building, advertisers indicate that the most important indicator of slogan effectiveness is the recall (Molian, 1993). In addition, Rosengren and Dahlén (2006) report that a slogan needs to be noticed (not liked), essentially in mature markets and brands.

If remembrance (recall and recognition) reflects the effectiveness of slogans, the studies of Dass et al. (2014) and Kohli et al. (2013) report that the characteristics of the slogan itself enhance both slogan likeability and recall. In this context, Kohli et al. (2013) mention that the amount of media exposure in terms of the slogan age and advertising spending have the major influences on slogan recall. In fact, individuals' recall of the slogan reflects their processing of advertising messages. This recall then affects their beliefs and attitude toward the brand. These brand assessments then affect behaviours in the marketplace, such as brand choice and loyalty (Vakratsas and Ambler, 1999), respectively represented by transaction likelihood and share-ofwallet.

Also, in the context of slogan recall relevance, there are several previous studies on slogans concerning the creation of slogans. In this stream, several authors mention that a slogan should be easy to remember and, consequently, the authors propose the ideal characteristics a slogan should have to achieve the goal of being remembered 
(Stewart and Clark, 2007; Kohli et al., 2007; Rosengren and Dahlén, 2005; Molian, 1993). Although, most of those papers were not empirically supported/tested, and several of them are based on researchers' own evaluations (Galí et al., 2016). Those studies usually identify or propose the intrinsic desirable characteristics of a slogan, but do not consider that the external factors might also contribute to the remembrance of the slogan. Notwithstanding, the literature is extensive on reporting that marketing performance is influenced by extrinsic factors besides the marketing actions of the firm. There are numerous extrinsic elements that might influence marketing performance, such as competitor actions, macroeconomic factors, social dynamics, consumer to consumer word-of-mouth, customer past behaviour, etc. Among those factors, loyalty and customer retention time are generally identified as extrinsic factors that might influence marketing performance (Blattberg et al., 2009).

Customer retention time ties in with studies on customer lifetime value, satisfaction, and loyalty. Customer satisfaction and customer retention are close (Rust and Zahorik, 1993), and is usually believed that long-lifetime customers are more profitable to a company (Blattberg et al., 2009; Jain and Singh, 2002). Hogan et al. (2004) demonstrate that customer lifetime value components provide an assessment of advertising effectiveness, where slogans are included. Purchase frequency is a component of customer lifetime value metric (Venkatesan and Kumar, 2004) and it might represent the relationship duration (Blattberg et al., 2009). So, it might be expected that the duration of the relationship between customers and brands affects advertising effectiveness, where slogan remembrance fits into. In fact, one the first studies on slogan by Katz and Rose (1969) found that familiarity with slogans increases with consumption. The rationale behind this expected result is twofold:

(i) Typically, an actual or registered customer receives more administrative and marketing information from the respective brand (e.g. bills, newsletters, up-selling proposals, cross-selling proposals) than non-customers (not interested individuals, competitor customers, prospects or leads). Those messages might include the slogan and, therefore, such higher exposition to the slogan might increase the slogan's recall and recognition.

(ii) An actual customer has interest on the respective brand, which probably increases the attention to the brand, making the customer more aware and alert to that brand messages, increasing the slogan recall and recognition.

Summarizing, the present research is based on the previous rationale that customer retention time might influence several marketing components, performance, and outputs. Due to that, it might be expected that the customer retention time might positively influence the effectiveness of marketing communications, namely the recall and recognition of brand slogans. Consequently, the main research question established was to analyze if "the customer retention time influences the 
remembrance of slogans". From that question, a statistically testable hypothesis was formulated as "a longer customer retention time makes the slogan more memorable".

To analyse this hypothesis, the target variables established were the recall and recognition of slogans, because both are the elements of memorability most commonly employed to evaluate awareness, slogan familiarity or correct/incorrect recall (Bauerly and Tripp, 1997; Rosengren and Dahlén, 2006).

\section{Research Methodology}

A descriptive and quantitative study was conceived to gather information from real consumers of three brands in the telecom business-to-consumer service-providers. The market is clearly dominated by the three brands analyzed and most of the customers are effectively registered as customers of one those brands. The industry is highly competitive and has high advertising investments, intensity, and exposures. All the three brands have consistently used their slogans in advertising and marketing communications efforts. The information used in the study was primary data, gathered via an online questionnaire, obtaining responses from 370 valid consumers. A two-stage non-random sampling was used, first with a convenience technique and, in a second stage, with a snow-ball technique. Besides demographics, the variables measured with the questionnaire were:

- Spontaneous slogan recall (spontaneous) for each one of the three brands, measured with the open question "What is the actual slogan for brand $X$ ?".

- Slogan recognition (assisted) for each one of the three brands. For each one of them, four options of slogans were presented: the actual and correct slogan of the brand, an older slogan of the brand, the oldest slogan of the brand, and the slogan of a competitor.

- Confidence on the recognition of the chosen slogan, measured in a five-item scale with ive-point Likert response options. The items used were: "I am sure that this slogan is not from another brand", "I am sure that this is the slogan that currently prevails", "I often hear that slogan on ads", "I often read that slogan on ads", "I quickly associate that slogan to the brand");

- Actual customer status measured in a dichotomous variable: customer or noncustomer;

- Customer retention time, measured in four classes: less than 1year, from 1 to 3 years, from 3 to 5 years, and more than 5 years.

\section{Findings}

Before analyzing the results directly associated with the research question, Table 1 presents the recall and recognition rates for each brand, with the intent of introducing the remembrance levels reported. As expected, the correct slogan recognition rates are considerably higher than the recall rates (brand A: 19,6\% vs 
$36,5 \%$; brand B 6,7\% vs 67,3\%; brand C: $20,1 \%$ vs $78 \%$ ). These values are coherent with Katz and Rose (1969), since those authors also found a considerable incorrect recall for slogans, especially in heavily advertised markets. The results also show that correctly matching the slogan and the featured brand remains a challenge for branding, probably due to the large number of advertising messages daily received by consumers, making it difficult the task to match a slogan to the correct brand (Huang and Lin, 2017).

Table 1. Correct and incorrect slogan recall and recognition rates

\begin{tabular}{|c|l|c|c|}
\hline Brand & \multicolumn{1}{|c|}{ Response } & Recall (spontaneous) & $\begin{array}{c}\text { Recognition } \\
\text { (assisted) }\end{array}$ \\
\hline A & Correct slogan & $19,6 \%$ & $36,5 \%$ \\
\hline A & Partially correct & $0,3 \%$ & - \\
\hline A & Incorrect slogan & $36,9 \%$ & $62,4 \%$ \\
\hline A & Doesn't know & $43,2 \%$ & $1,1 \%$ \\
\hline B & Correct slogan & $6,7 \%$ & $67,3 \%$ \\
\hline B & Partially correct & $0,5 \%$ & - \\
\hline B & Incorrect slogan & $30,3 \%$ & $28,1 \%$ \\
\hline B & Doesn't know & $62,5 \%$ & $4,6 \%$ \\
\hline C & Correct slogan & $20,1 \%$ & $78,0 \%$ \\
\hline C & Partially correct & $0,3 \%$ & - \\
\hline C & Incorrect slogan & $4,5 \%$ & $17,1 \%$ \\
\hline C & Doesn't know & $75,1 \%$ & $4,8 \%$ \\
\hline
\end{tabular}

Considering only the correct slogan recognitions, a multi-item scale was used to access the respondents' confidence on such recognition. The results are shown in Table 2 and the respondents were confident with the choice made. This is true for each one of the three brands analysed. In fact, the mean for each item is on the top end of the Likert scale used, ranging from a minimum mean of 3,86 to a maximum mean of 4,47 .

These results are an indicator that the recognition made was not by chance but, instead, probably due to direct marketing efforts or to consuming history, learning or experience. If the correct recognition and recall of slogans was not by chance, the respective rates were crosstabbed with the actual customer status for each brand (Table 3).

The recall rates found are higher for current customers than for non-customers. This was observed in each one of the brands studied. A similar scenario was verified analysing the slogan recognition instead of the recall. In table 3, for each brand, it is possible to notice a higher percentage of current customers than non-customers that were able to recall the correct slogan for each brand. 
Table 2. Confidence on the slogan recognition made (for totally correct responses)

\begin{tabular}{|l|c|c|c|}
\hline & Brand & Brand & Brand \\
Item of confidence on the chosen slogan & A & B & C \\
\hline I am sure that this slogan is not from another brand & $\overline{\boldsymbol{x}}$ & $\overline{\boldsymbol{x}}$ & $\overline{\boldsymbol{x}}$ \\
I am sure that this is the slogan that currently prevails & 4,47 & 4,17 & 4,39 \\
I often hear that slogan on ads & 4,29 & 3,86 & 3,99 \\
I often read that slogan on ads & 4,01 & 3,87 & 3,95 \\
I quickly associate that slogan to the brand & 4,15 & 4,08 & 4,03 \\
& & & \\
[all items] & 4,27 & 3,97 & 4,09 \\
\hline
\end{tabular}

Table 3. Correct slogan recall and recognition rates by type of customer

\begin{tabular}{|l|c|c|}
\hline \multicolumn{1}{|c|}{ Type of customer } & $\begin{array}{c}\text { Correct Slogan Recall } \\
\text { (spontaneous) }\end{array}$ & $\begin{array}{c}\text { Correct Slogan } \\
\text { Recognition (assisted) }\end{array}$ \\
\hline Brand A & $18.8 \%$ & $34.8 \%$ \\
- non-customers & $22.9 \%$ & $40.7 \%$ \\
- current customers & $7.5 \%$ & $70,4 \%$ \\
\hline Brand B & $10.3 \%$ & $71.6 \%$ \\
- non-customers & & \\
- current customers & & \\
\hline Brand C & $14.0 \%$ & $78,8 \%$ \\
- non-customers & $23.2 \%$ & $85,0 \%$ \\
- current customers & & \\
\hline
\end{tabular}

So, analysing Table 3, it seems that the current customers of each brand would have a higher probability of recalling the slogan of that same brand. Although, as presented in table 4 , the statistical testing did not show significant differences between customers and non-customers, since that no null hypothesis was rejected for $\mathrm{p}=.05$.

This is also confirmed by the logistic regression Forward:LR, whose results revealed that being an actual customer did not present a significant statistical effect on the Logit of the probability of slogan spontaneous recall. This result was verified in all the brands studied - brand A $\left(b=0.056 ; X^{2}\right.$ Wald $\left.(1)=0.032 ; p=0.858\right)$, brand B $(b=-$ $0.094 ; X^{2}$ Wald $\left.(1)=0.038 ; p=0.846\right)$ and brand $\mathrm{C}\left(b=-0.288 ; X^{2}{ }_{\text {Wald }}(1)=0.228 ; p=0.633\right)$.

Again, the same was observed regarding the recognition rates. Testing the recognition rates differences between customers and non-customers with MannWhitney test, no significant differences were found (Table 4).

Besides that, the logistic regression Forward: LR results showed that being an actual customer did not have a significant statistical effect on the on the Logit of the probability of assisted slogan recognition. Again, this result was verified in each of 
the three brands - brand A $\left(b=-0.252 ; X^{2}\right.$ Wald $\left.(1)=1.188 ; p=0.276\right)$; brand B $(b=-0.008$; $X^{2}$ Wald $\left.(1)=0.001 ; p=0.978\right)$; brand C $\left(b=-0.528 ; X^{2}\right.$ Wald $\left.(1)=3.620 ; p=0.057\right)$.

Table 4. Recall and recognition differences tests between customers and noncustomers

\begin{tabular}{|l|c|c|}
\hline Brand & $\begin{array}{c}\text { Spontaneous Recall } \\
\text { Sig. } \boldsymbol{U}^{*}\end{array}$ & $\begin{array}{c}\text { Assisted Recognition } \\
\text { Sig. } \boldsymbol{U}^{*}\end{array}$ \\
\hline Brand A & 0,489 & 0,164 \\
\hline Brand B & 0,363 & 0,301 \\
\hline Brand C & 0,065 & 0,466 \\
\hline
\end{tabular}

Note: * exact sig. 1-tailed applying Mann-Whitney test

**rejection of the null hypothesis for $p=0.05$. In such variables (none), the recall/recognition was significantly higher in the group that correctly recalled/recognized the slogan.

Detailing the analysis, specifying it only to the actual customers of each brand, Table 5 presents the slogans' recall and recognition rates by customer seniority category. Considering the recall rates, it does not seem to emerge any clear pattern of direct relation between time and higher recall rates, as presented in Table 5.

For example, in brand A, the third class ( 3 to 5 years) is the one with a higher slogan recall rate, but in brand $\mathrm{B}$ that class is the one with the lower rate, and in Brand $\mathrm{C}$ it is the one in the middle. Considering the recognition rates, it is also not clear any direct relation. Most of these results also have support in Table 6, showing almost no differences between any of the retention time classes on each brand studied (the only exception is the recognition rates on brand C).

Table 5. Correct slogan recall and recognition by customer retention time

\begin{tabular}{|l|c|c|}
\hline Customer retention time & $\begin{array}{c}\text { Correct Slogan } \\
\text { Spontaneous Recall }\end{array}$ & $\begin{array}{c}\text { Correct Slogan Assisted } \\
\text { Recognition }\end{array}$ \\
\hline Brand A & $25.0 \%$ & $37.5 \%$ \\
- less 1 year & $17.2 \%$ & $37.9 \%$ \\
- 1 to 3 years & $33.3 \%$ & $42.9 \%$ \\
- 3 to 5 years & $22.4 \%$ & $41.1 \%$ \\
- more than 5 years & & \\
\hline Brand B & $9.1 \%$ & $54.5 \%$ \\
- less 1year & $13.3 \%$ & $85.7 \%$ \\
- 1 to 3 years & $0.0 \%$ & $81.2 \%$ \\
- 3 to 5 years & $13.9 \%$ & $66.7 \%$ \\
- more than 5 years & & \\
\hline Brand C & $14.3 \%$ & $85.7 \%$ \\
- less 1year & $18.9 \%$ & $83.3 \%$ \\
- 1 to 3 years & $15.4 \%$ & $84.2 \%$ \\
- 3 to 5 years & $27.5 \%$ & $85.6 \%$ \\
- more than 5 years & \multicolumn{2}{|}{} \\
\hline
\end{tabular}


Table 6. Recall and recognition differences tests between the four groups of retention time

\begin{tabular}{|l|c|c|}
\hline Customer retention time & Recall Sig. $\boldsymbol{U}^{*}$ & Recognition Sig. $\boldsymbol{U}^{*}$ \\
\hline Brand A & 0,230 & 0,422 \\
\hline Brand B & 0,512 & 0,548 \\
\hline Brand C & 0,422 & $0,040^{* *}$ \\
\hline
\end{tabular}

Note: * exact sig. 1-tailed applying Mann-Whitney test

** rejection of the null hypothesis for $p=0.05$. In such variables (only one), the recall/recognition was significantly higher in the group that correctly recalled/recognized the slogan.

\section{Conclusions}

In summary, our study intended to add value to more informed and effective design and management of slogans, in the context of branding and advertising, by understanding if the customer retention time has a positive influence on the recall and recognition of slogans.

The main research question established in this study was to analyze if "the customer retention time influences the remembrance of slogans". The study findings gave us indicators that point to a non-existent relationship between the correct recognition and recall of slogans and the customer seniority category. The lack of this relation also applies in the comparative analysis between current customers and noncustomers.

Despite the study of Katz and Rose (1969) that pointed to a relationship between consumption and increased familiarity with slogans, our study did not find a relation between the ability of individuals to recall and recognize a brand slogan and the duration of their relationship as consumers of a company. Still, although the relationships described by Kohli et al. (2013) between the amount of media exposure in terms of slogan age and advertising spending, and the recall slogan, our findings on consumer seniority do not support a parallel result. That is, if there is no relationship between remembrance slogans and consumer retention time, consumer exposure to more administrative and brand marketing information (and to everything that encompasses their contact with the brand) compared to a non-consumer, or of a new consumer in comparison to an older one, does not necessarily increase slogan recall or recognition.

Therefore, the marketing and communication efforts of the brands with their current customers do not seem to have an impact on the increase of the recall rate and recognition of their slogans. Based on these results, marketing communication strategies focused on their customers should consider that these individuals are not necessarily more familiar with the brand aspects that are communicated through the slogan. So, if the brand aims to achieve a more memorable position in the 
individuals' mind through the slogan, the marketing respective marketing actions should not differentiate the effort level between more recent customers, noncustomers and more senior customers.

The study has limitations that further studies can address. The sampling technique used was not random, conditioning its representativeness. This research option leads to suggest the replication of this study in other samples, to test the conclusions we have reached. The results of this study are from the telecom industry, meaning that further studies need to investigate whether the results are generalizable to other industries as well as to provide a more comprehensive picture.

\section{References:}

Bauerly, R.J., Tripp, C. 1997. Developing slogans for marketing of higher education. Journal of Marketing for Higher Education, 8(1), 1-14.

Blattberg, R.C., Malthouse, E.C., Neslin, S.A. 2009. Customer lifetime value: Empirical generalizations and some conceptual questions. Journal of Interactive Marketing, 23(2), 157-168.

Boush, D. 1993. How Advertising Slogans Can Prime Evaluations of Brand Extensions. Psychology and Marketing, 10(1), 67-78.

Briggs, E., Janakiraman, N. 2017. Slogan recall effects on marketplace behaviors: The roles of external search and brand assessment. Journal of Business Research, 80, 98-105.

Dahlén, M., Rosengren, S. 2005. Brands affect slogans affect brands? Competitive interference, brand equity and the brand-slogan link. Journal of Brand Management, 12(3), 151-164.

Dass, M., Kohli, C., Kumar, P., Thomas, S. 2014. A study of the antecedents of slogan liking. Journal of Business Research, 67(12), 2504-2511.

Dowling, G.R., Kabanoff, B. 1996. Computer-aided content analysis: What do 240 advertising slogans have in common? Marketing Letters, 7(1), 63-75.

Galí, N., Camprubí, R., Donaire, J.A. 2017. Analyzing tourism slogans in top tourism destinations. Journal of Destination Marketing and Management, 6(3), 243-251.

Hodges, B., Warren, C., Estes, Z. 2016. More Than Words: a Psycholinguistic Perspective on the Properties of Effective Brand Slogans, in NA - Advances in Consumer Research Volume 44, eds. Page Moreau and Stefano Puntoni, Duluth, MN: Association for Consumer Research, 478-479.

Hogan, J.E., Lemon, K.N., Libai, B. 2004. Quantifying the ripple: Word-of-mouth and advertising effectiveness. Journal of Advertising Research, 44(3), 271-280.

Huang, S.C.L., Lin, L.P.L. 201. Awareness Effects of the Tourism Slogans of Ten Destinations in Asia. Journal of China Tourism Research, 13(4), 375-387.

Jain, D., Singh, S.S. 2002. Customer lifetime value research in marketing: A review and future directions. Journal of Interactive Marketing, 16(2), 34-46.

Katz, M., Rose, J. 1969. Is your slogan identifiable? Journal of Advertising Research, 9(1), 21-26.

Keisidou, E., Sarigiannidis, L., Maditinos, D. and Thalassinos, I.E. 2013. Customer 
satisfaction, loyalty and financial performance: A holistic approach of the Greek banking sector. Marketing Intelligence and Planning, 31(4), 259-288, Emerald Group Publishing Ltd., DOI: 10.1108/IJBM-11-2012-0114.

Kohli, C., Leuthesser, L., Suri, R. 2007. Got slogan? Guidelines for creating effective slogans, Business Horizons, 50, 415-422.

Kohli, C., Thomas, S., Suri, R. 2013. Are You In Good Hands? Journal of Advertising Research, 53(1), 31-42.

Laran, J., Dalton, A., Andrade, E. 2011. The Curious Case of Behavioral Backlash: Why Brands Produce Priming Effects and Slogans Produce Reverse Priming Effects. Journal of Consumer Research, 37(6), 999-1014.

Miller, D.W., Toman, M. 2014. An analysis of rhetorical figures and other linguistic devices in corporation brand slogans. Journal of Marketing Communications, 120.

Miller, D.W., Toman, M. 2015. An Analysis of the Syntactic Complexity in Service Corporation Brand Slogans. Services Marketing Quarterly, 36(1), 37-50.

Molian, D. 1993. I am a doughnut: Lessons for the sloganeer. European Business Journal, 5(2), 40-47.

O'guinn, T.C., Allen, C.T., Semenik, R.J. 2011. Advertising and integrated brand promotion. South-Western Pub.

Pryor, K., Brodie, R. 1998. How advertising slogans can prime evaluations of brand extensions: further empirical results. The Journal of Product and Brand Management, 7(6), 497-508.

Rosengren, S., Dahlén, M. 2006. Brand-Slogan Matching in a Cluttered Environment. Journal of Marketing Communications, 12(4), 263-279.

Rust, R.T., Zahorik, A.J. 1993. Customer satisfaction, customer retention, and market share. Journal of Retailing, 69(2), 193-215.

Stewart, J., Clark, M. 2007. The Effect of Syntactic Complexity, Social Comparison, and Relationship Theory on Advertising Slogan. The Business Review, Summer, 7(1), 113-118.

Strutton, D., Roswinanto, W. 2014. Can vague brand slogans promote desirable consumer responses? Journal of Product \& Brand Management, 23(4/5), 282 294.

Supphellen, M., Nygaardsvik, I. 2002. Testing Country Brand Slogans: Conceptual Development and Empirical Illustration of a Simple Normative Model. Journal of Brand Management, 9(4/5), 385-395.

Vakratsas, D., Ambler, T. 1999. How Advertising Works: What Do We Really Know? Journal of Marketing, 63(1), 26-43.

Venkatesan, R., Kumar, V. 2004. A customer lifetime value framework for customer selection and resource allocation strategy. Journal of Marketing, 68(4), 106-125.

Wang, W.C., Silva, M.M.S., Moutinho, L. 2016. Modelling Consumer Responses to Advertising Slogans through Artificial Neural Networks. International Journal of Business and Economics, 15(2), 89-116. 